\title{
Levels of disaccharidases in the brush border membrane of equine small intestine
}

\author{
M.A. Alrammahi \\ Department of Physiology, Biochemistry and Pharmacology, College of Veterinary Medicine, University of Al-Qadisiyah, \\ Al-Diwaniyha, 58001, Iraq, Email: miran.alrammahi@qu.edu.iq
}

(Received June 1, 2019; Accepted June 25, 2019)

\begin{abstract}
The disaccharides, consisting of sucrose, lactose and maltose, are hydrolysed into monosaccharides (D-glucose, D-galactose and D-fructose) by intestinal brush border enzymes: sucrase, lactase and maltase. The aim of this study to investigate changes in the brush-border membrane carbohydrate digestive enzymes. From intestinal mucosal scrapings of equine, brush border membrane vesicles were isolated. The results showed that sucrase, maltase and lactase are present in the equine small intestine. The activity of all three enzymes is highest proximally (in the duodenum and jejunum) and lower in the ileum. There was considerable variation between individual horses, however the majority showed highest disaccharidase activity in the jejunum, with some showing highest activity in the duodenum. Sucrase activity is highest in the jejunum and duodenum and lower in the ileum. Maltase activity is similar in all three regions, but slightly higher in the jejunum. Lactase activity is low in all three regions of the small intestine, slightly higher in the equine jejunum and duodenum than ileum. From this study, we can conclude that the equine small intestine digests disaccharides by the brush-border associated disaccharidases sucrase, maltase and lactase. Levels of sucrase and lactase are comparable to other species, but maltase is much higher.
\end{abstract}

Keywords: Brush border membrane vesicle, Sucrase, Maltase, Lactase, Equine small intestine Available online at http://www.vetmedmosul.com, () 2020, College of Veterinary Medicine, University of Mosul. This is an open access article under the CC BY 4.0 license (http://creativecommons.org/licenses/by/4.0/).

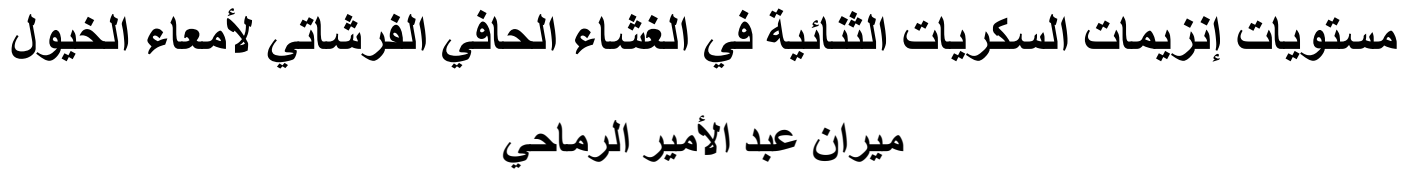

فرع الفسلجة، الكمياء الحياتية والأدوية، كلية الطب البيطري، جامعة القادية، القادية، العراق

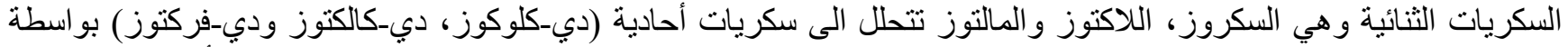

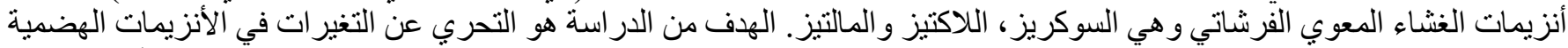

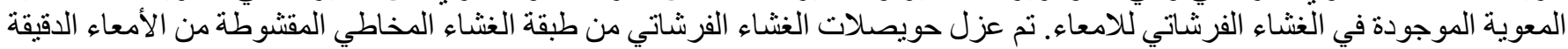

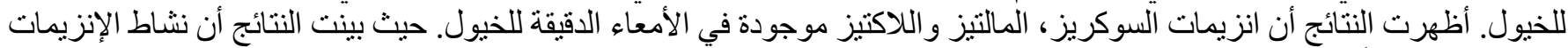

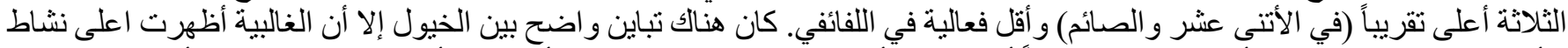

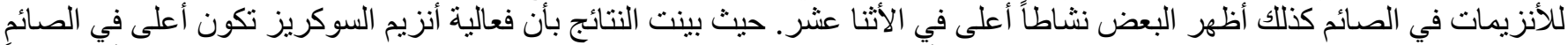

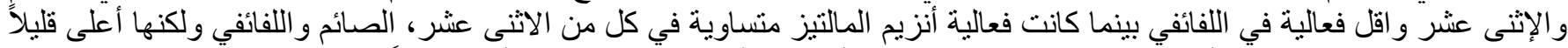

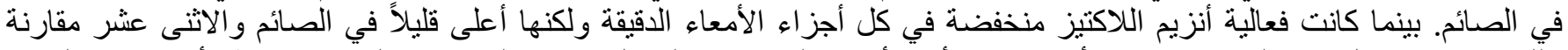

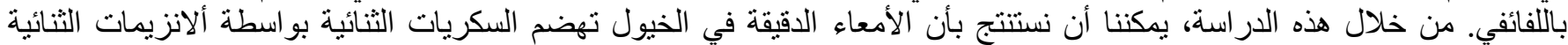

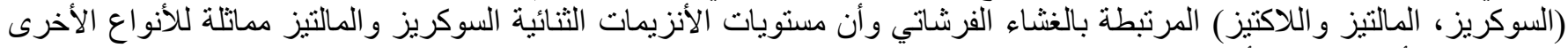

$$
\text { ولكن مستوى أنزيم المالتيز أعلى بكثير. }
$$




\section{Introduction}

In non-ruminant herbivore species, such as horse, the natural diet is grass from pasture forage. The large intestine (caecum and colon) of horses is an immensely enlarged fermentative chamber which contains a uniquely adapted microbial population (1-3). The microbial fermentation of dietary plant fibre leads to the production of monocarboxylates, acetate, propionate and butyrate, often referred to as short chain fatty acids (SCFAs). The absorption of these SCFAs via the colonic epithelium provides a significant proportion of the horse's energy requirements (1-3). Today's horses are normally fed more concentrate-based diets containing high levels of digestible carbohydrates (2). It is therefore important that in order to prevent intestinal dysfunction, horses are able to digest these carbohydrates before they enter the large intestine (3). It has been shown in many species that digestible carbohydrates are hydrolysed into their component monosaccharides in the lumen of small intestine by pancreatic $\alpha$-amylase and the brush border membrane disaccharidases (sucrase, maltase and lactase) $(4,5)$. Sucrase hydrolyses sucrose into glucose and fructose, lactase hydrolyses lactose into glucose and galactose, and maltase hydrolyses maltose into two molecules of glucose (6). Glucose and galactose are then transported across the brush border membrane (BBM) of intestinal enterocytes via the sodium-dependant glucose transporter SGLT1 (7-9), while fructose is absorbed into the enterocyte via the sodium-independent fructose transporter GLUT5 (9-11). These monosaccharides are then transported into systemic circulation across the basolateral membrane of the intestinal enterocyte via the sodium-independent monosaccharide transporter, GLUT2 $(4,5,8,10)$.

The aim of this study is to investigate expression of brush-border membrane carbohydrate digestive enzymes in the equine small intestine.

\section{Material and methods}

\section{Animals and collection of tissue samples}

Intestinal samples from duodenum, jejunum and ileum from 7 mature horses aged 4-6 years were collected from a local abattoir in Neston, UK and treated as described by AlRammahi (12).

\section{Brush border membrane vesicles}

From equine small intestinal mucosal scrapings, brush border membrane vesicles (BBMV) were isolated using a method based on that by $(13)$ as described $(3,12)$. The final pellet which containing purified BBMV was homogenized by passing through a 27 gauge needle several times in 0.1 $\mathrm{mM} \mathrm{MgSO}_{4}, 300 \mathrm{mM}$ mannitol, $0.02 \%$ (w/v) $\mathrm{NaN}_{3}$ and 20 mM HEPES/Tris, pH 7.4 buffer. Until used, the BBMV were aliquoted and stored in liquid nitrogen. All steps were carried out at ${ }^{+} 4^{\circ} \mathrm{C}(5,12)$.

\section{Estimation of protein}

According to the Bio-Rad assay technique, the protein concentration was estimated in the BBMVs using its ability to bind Coomassie Brilliant Blue G250 in acidic conditions. We used the bovine $\gamma$-globulin as a standard $(12,14,15)$.

\section{Disaccharidase activity}

In a glass test-tube, $50 \mu 1$ of BBMV was placed (in triplicate). The samples were placed in a water bath at $37^{\circ} \mathrm{C}$ and allowed to reach temperature as described previously $(2,3,14)$. The reaction was started by the addition of $50 \mu \mathrm{l}$ assay mix (depending on which enzyme was being assayed); Sucrase - $100 \mathrm{mM}$ NaH Maleate $\mathrm{pH} 6.0,56 \mathrm{mM}$ Sucrose; Lactase - $100 \mathrm{mM} \mathrm{NaH}$ Maleate $\mathrm{pH}$ 6.0, $56 \mathrm{mM}$ Lactose, 200 $\mathrm{mM}$ para-Chloromercuric Benzoate (PCMB) and Maltase $100 \mathrm{mM} \mathrm{NaH}$ Maleate $\mathrm{pH}$ 6.0, $56 \mathrm{mM}$ Maltose. Then incubated at $37{ }^{\circ} \mathrm{C}$ for 15 minutes. The reactions were stopped by placing the tubes in a boiling water bath at 100 ${ }^{\circ} \mathrm{C}$ for 2 minutes and then cooling them to room temperature. $1 \mathrm{ml}$ of Solution 1 (Boehringer Mannheim; containing Triethanolamine buffer $\mathrm{pH}$ 7.6, NADP, ATP and $\mathrm{MgSO}_{4}$ ) and $1.9 \mathrm{ml}$ double distilled $\mathrm{H}_{2} \mathrm{O}$ were added to each tube and the solution mixed. Finally, $20 \mu \mathrm{l}$ of Suspension 2 (Boehringer Mannheim; containing hexokinase, glucose-6phosphate dehydrogenase) were added to each tube and the reaction mixed and allowed to stand for 15 minutes. Afterwards aliquots were placed in $1 \mathrm{ml}$ cuvettes and the absorbance of $1 \mathrm{~cm}$ path length at $340 \mathrm{~nm}$ was measured (U2000 Spectrophotometer, Hitachi).

\section{Statistical Analysis}

Data are presented as means \pm SEM. Significance statistical comparisons were determined by using one-way analysis of variance (ANOVA). Results were considered significant when $P$ values $<0.05$.

\section{Results}

\section{Sucrase}

The enrichment (6.6-10.6 fold) of sucrase activity in vesicles over homogenate confirmed that the membrane vesicles isolated were of BBM. The results showed that sucrase specific activity $(\mu \mathrm{mol} / \mathrm{min} / \mathrm{mg}$ protein) in the 3 regions of the small intestine of 7 grass-fed horses is highest in the proximal small intestine (duodenum and jejunum) compared to the distal (ileum) (table 1), and this data is represented as a histogram in figure 1.

\section{Maltase}

The results showed that maltase activity $(\mu \mathrm{mol} / \mathrm{min} / \mathrm{mg}$ protein) of 7 grass-fed horses is similar in all regions of the 
small intestine table 2, and this data is represented as a histogram in figure 2.

\section{Lactase}

The finding showed that the lactase specific activity ( $\mu \mathrm{mol} / \mathrm{min} / \mathrm{mg}$ protein) in 3 regions of the small intestine of
7 grass-fed horses is highest in the proximal small intestine (jejunum $>$ duodenum) compared to the distal (ileum). Table 3 shows the lactase specific activity, and this data is presented as a histogram in figure 3 .

Table 1: Specific activity of sucrase

\begin{tabular}{lccccccc}
\hline & \multicolumn{7}{c}{ Sucrase Specific Activity $(\mu \mathrm{mol} / \mathrm{min} / \mathrm{mg}$ protein $)$} \\
\cline { 2 - 8 } & Homogenate & SEM & $\mathrm{n}$ & Vesicles & SEM & $\mathrm{n}$ & Enrichment \\
\hline Duodenum & 0.036 & 0.006 & 7 & $0.380^{\text {ns }}$ & 0.078 & 7 & 10.6 \\
Jejunum & 0.042 & 0.010 & 7 & $0.395^{*}$ & 0.075 & 7 & 9.4 \\
Ileum & 0.033 & 0.004 & 7 & $0.216^{*}$ & 0.029 & 7 & 6.6 \\
\hline
\end{tabular}

Enrichment is fold-increase of sucrase specific activity in BBMV over homogenate, $* P<0.05$, ns not significant.

Table 2: Specific activity of maltase

\begin{tabular}{lccccccc}
\hline & \multicolumn{7}{c}{ Sucrase Specific Activity $(\mu \mathrm{mol} / \mathrm{min} / \mathrm{mg}$ protein $)$} \\
\cline { 2 - 8 } & Homogenate & SEM & $\mathrm{n}$ & Vesicles & SEM & $\mathrm{n}$ & Enrichment \\
\hline Duodenum & 0.059 & 0.008 & 7 & $0.831^{\mathrm{ns}}$ & 0.113 & 7 & 14.1 \\
Jejunum & 0.075 & 0.016 & 7 & $0.908^{\mathrm{ns}}$ & 0.106 & 7 & 12.1 \\
Ileum & 0.086 & 0.011 & 7 & $0.776^{\mathrm{ns}}$ & 0.111 & 7 & 9.1 \\
\hline
\end{tabular}

Enrichment is fold-increase of maltase specific activity in BBMV over cellular homogenates, ns not significant.

\section{Sucrase Activity \\ Grass-fed Horses ( $n=7$ )}

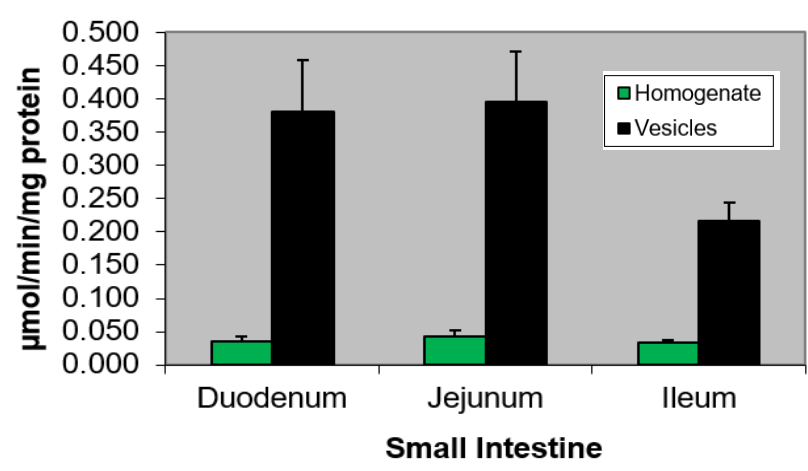

Figure 1: Sucrase specific activity in all 3 regions of the equine small intestine showing the enrichment in BBMV over cellular homogenates.

\section{Maltase Activity Grass-fed Horses $(n=7)$}

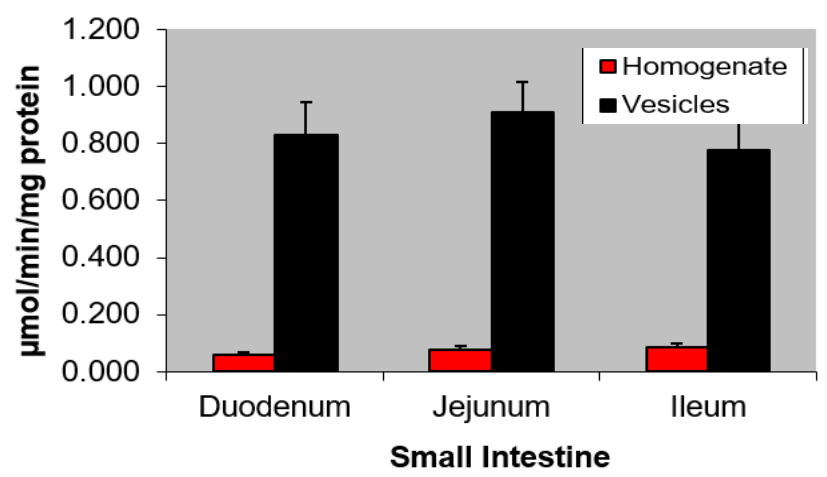

Figure 2: Maltase specific activity in all 3 regions of the equine small intestine showing the enrichment of in BBMV over cellular homogenates.

Table 3: Specific activity of lactase

\begin{tabular}{lccccccc}
\hline & \multicolumn{7}{c}{ Sucrase Specific Activity $(\mu \mathrm{mol} / \mathrm{min} / \mathrm{mg}$ protein) } \\
\cline { 2 - 8 } & Homogenate & SEM & $\mathrm{n}$ & Vesicles & SEM & $\mathrm{n}$ & Enrichment \\
\hline Duodenum & 0.030 & 0.004 & 7 & $0.082^{\text {ns }}$ & 0.024 & 7 & 2.7 \\
Jejunum & 0.029 & 0.005 & 7 & $0.100^{\text {ns }}$ & 0.030 & 7 & 3.4 \\
Ileum & 0.025 & 0.005 & 7 & $0.047^{\text {ns }}$ & 0.006 & 7 & 1.9 \\
\hline
\end{tabular}

Enrichment is fold-increase of maltase specific activity in BBMV over cellular homogenates, ns not significant. 


\section{Lactase Activity Grass-fed Horses ( $n=7$ )}

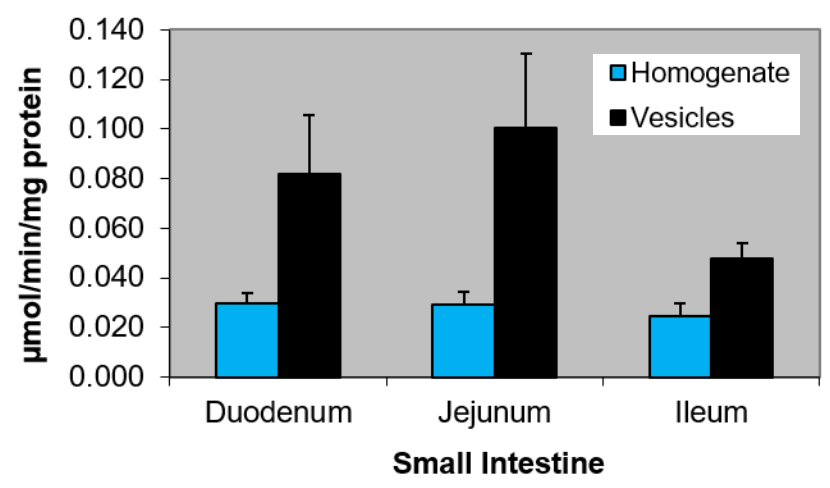

Figure 3: Histogram of lactase specific activity in all 3 regions of the equine small intestine showing the enrichment in vesicles over cellular homogenates.

\section{Discussion}

The horses' natural diet, grass from pasture forage, undergoes seasonal variation in its soluble (hydrolysable) carbohydrate content (16). However, this variation is much less than in the natural diet of most omnivores, and is certainly less than the difference between grass and the high grain (starch) concentrate diets fed to many horses in managed environments (3). It has previously been proposed that the equine intestine may have a slower or blunted adaptive response to dietary change (17), which is be an important consideration for the development of dietaryinduced intestinal dysfunction in horses. It is not known however if the slower adaptive response is in the digestion or the absorption of dietary carbohydrates. Starch is mainly hydrolysed in the small intestine by pancreatic $\alpha$-amylase and the intestinal brush-border membrane disaccharidase, maltase, to glucose $(18,19)$.

We can see here that the activity of maltase in the equine jejunum $(0.908 \mu \mathrm{mol} / \mathrm{min} / \mathrm{mg})$ is up to 3 times higher than that in other species such as pig $(0.306 \mu \mathrm{mol} / \mathrm{min} / \mathrm{mg})$ and cat $(0.400 \mu \mathrm{mol} / \mathrm{min} / \mathrm{mg})(2)$ and it is therefore unlikely that there is a deficiency in maltase activity limiting starch digestion in the horse $(20,21)$. However, it has been shown that the levels and activity of $\alpha$-amylase in the equine intestine are low compared to other species $(4,5)$, and it would seem probable that the initial breakdown of starch into maltose, maltotriose, and $\alpha$-dextrin is the limiting step of starch digestion in horses given concentrate diets containing large amounts of grain (22).

In this study, we compared the activity of disaccharidases along the length of the small intestine of horses maintained on grass. In the horse small intestine, SGLT1 is only slowly upregulated over time, a lag period which may be due to the time required for $\alpha$-amylase upregulation and greater rates of starch hydrolysis (3). Studies carried out in other species have indicated that there is an adaptive response in amylase expression and activity in response to increases in hydrolysable dietary carbohydrates (23). This is also true in horse, however, the rate of increase is much smaller than in omnivorous species such as pigs or even in the carnoomnivorous dog Kienzle et al (21) suggesting that a longer term adaptation period is needed for enhancement in $\alpha$ amylase activity in response to increased dietary hCHO in horse (22). Increased knowledge of the digestive system of the horse, and insight into the underlying mechanisms of intestinal adaptation in response to a change in diet, will help to improve the development of scientifically-based dietary strategies that could be used to modify the capacity of the equine intestine to digest hydrolysable carbohydrates with the aim of enhancing feed formulation and improving the health and welfare of the horse.

\section{Conclusion}

From these results it is clear that the equine small intestine is expressing disaccharidases in the brush border membrane. The equine small intestine is capable of digesting disaccharides by the brush-border associated disaccharidases sucrase, maltase and lactase. Levels of sucrase and lactase are comparable to other species, but maltase is much higher.

\section{Acknowledgements}

We wish to thank Professor Dr. Soraya Shirazi-Beechey for her support and allow us to work in her laboratory at Department of Functional \& Comparative Genomics, Institute of Integrative Biology, University of Liverpool.

\section{References}

1. Daly K, Stewart C, Flint HJ, Shirazi-Beechey SP. Bacterial diversity within the equine large intestine as revealed by molecular analysis of cloned 16S rRNA genes. FEMS Micrbiol Ecol. 2001;38:141-151. doi.org/10.1111/j.1574-6941.2001.tb00892.x.

2. Dyer J, Fernandez ME, Salmon KS, Proudman CJ, Edwards GB, Shirazi SP. Molecular characterisation of carbohydrate digestion and absorption in equine small intestine. Equine Vet J. 2002;34:349-358. DOI: $10.2746 / 042516402776249209$

3. Dyer J, Al-Rammahi M, Waterfall L, Salmon KS, Geor RJ, Bouré L, Edwards GB, Proudman CJ, Shirazi-Beechey SP. Adaptive response of equine intestinal $\mathrm{Na}+$ /glucose co-transporter (SGLT1) to an increase in dietary soluble carbohydrate. Pflugers Arch. 2009;458(2):419-30. DOI 10.1007/s00424-008-0620-4.

4. Batchelor DJ, Al-Rammahi M, Moran AW, Brand JG, Li X, Haskins M, German AJ, Shirazi-Beechey SP. Sodium/glucose cotransporter-1, sweet receptor, and disaccharidase expression in the intestine of the domestic dog and cat: two species of different dietary habit. Am J Physiol Regul Integr Comp Physiol. 2011;300(1):67-75. DOI:10.1152/ajpregu.00262.2010. 
5. Moran AW, Al-Rammahi MA, Arora DK, Batchelor DJ, Coulter EA, Ionescu C, Bravo D, Shirazi-Beechey SP. Expression of Na+/glucose co-transporter 1 (SGLT1) in the intestine of piglets weaned to different concentrations of dietary carbohydrate. Br J Nutr. 2010;104(5):647-55. DOI: $10.1017 /$ S0007114510000954

6. Laurence C, Peter RK. Sugars, fatty acids, and energy biochemistry. New York: Blackwell; 2016. 17-30 p.

7. Shirazi SP. Molecular biology of intestinal glucose transport. Nut Res Rev. 1995;8:27-41. doi: 10.1079/NRR19950005.

8. Moran AW, Al-Rammahi MA, Batchelor DJ, Bravo DM, ShiraziBeechey SP. Glucagon-like peptide-2 and the enteric nervous system are components of cell-cell communication pathway regulating intestinal Nat/glucose co-transport. Front Nutr. 2018;26(5):101. doi.org/10.3389/fnut.2018.00101

9. Röder PV, Geillinger KE, Zietek TS, Thorens B, Koepsell H, Daniel H. The role of SGLT1 and GLUT2 in intestinal glucose transport and sensing. PLoS One. 2014;26;9(2):89977. DOI:10.1371/journal.pone. 0089977.

10. Wright EM, Loo DD, Hirayama BA. Biology of human sodium glucose transporters. Physiol Rev. 2011;91(2):733-94. doi: 10.1152/physrev .00055 .2009 .

11. Veronique D, Ronaldo PF. The role of fructose transporters in diseases linked to excessive fructose intake. J Physiol. 2013;591(2):401-414. doi.org/10.1177/2050640613505279.

12. Al Rammahi MA. Isolate and characterise brush border membrane vesicles and basolateral membrane vesicles from equine small intestine. Inter J Adv Res. 2014;2(7):924-930.

13. Shirazi SP, Davies AG, Tebbutt K, Dyer J, Ellis A, Taylor CJ, Fairclough P, Beechey RB. Preparation and properties of brush-border membrane vesicles from human small intestine. Gastroenterol. 1990;98:676-685. DOI:10.1016/0016-5085(90)90288-c
14. Dahlqvist A. Assay of intestinal disaccharidases. Scand J Clin Lab Invest. 1984;44:169-172. doi.org/10.1016/0003-2697(68)90263-7

15. Tarpey PS, Wood IS, Shirazi SP, Beechey RB. Amino acid sequence and the cellular location of the $\mathrm{Na}(+)$-dependent $\mathrm{D}$-glucose symporters (SGLT1) in the ovine enterocyte and the parotid acinar cell. Biochem J. 1995;15(312):293-300. doi: 10.1042/bj3120293.

16. Hoffman RM, Wilson JA, Kronfeld DS, Cooper WL, Lawrence LA, Sklan D, Harris PA. Hydrolyzable carbohydrates in pasture, hay, and horse feeds: direct assay and seasonal variation. J Anim Sci. 2001;79:500-506. DOI: 10.2527/2001.792500x.

17. Buddington RK, Rashmir AM. Carbohydrate digestion by the horse: is there a limiting factor. Equine Vet J. 2002;34:326-327. DOI: $10.2746 / 042516402776249100$

18. Shirazi SP. Molecular biology of intestinal glucose transport. Nutr Res Rev. 1995;8:27-34. doi: 10.1079/NRR19950005.

19. Shirazi SP. Intestinal sodium-dependent D-glucose co-transporter: Dietary regulation. Proc Nutr Soc. 1996;55:167-178. doi.org/10.1079/PNS19960018

20. Roberts MC, Hill FWG, Kidder DE. The development and distribution of small intestinal disaccharidases in the horse. Res Vet Sci. 1974;17:42-48. doi.org/10.1016/S0034-5288(18)33706-8

21. Kienzle E, Radicke S, Landes E, Kleffken D, Illenseer M, Meyer H. Activity of amylase in gastrointestinal tract of horse. J Anim Physiol Anim Nutr. 1994;72:234-241. doi.org/10.1111/j.1439-0396.1994. tb00392.x

22. Richards N, Choct M, Hinch GN, Rowe JB. Examination of the use of exogenous $\alpha$-amylase and amyloglucoside to enhance starch digestion in the small intestine of horse. Anim Feed Sci Technol. 2004;114:295305. doi.org/10.1016/j.anifeedsci.2003.09.004

23. Brannon RM. Adaptation of exocrine pancreas to diet. Ann Rev Nutr. 1990;10:85-105. doi.org/10.1146/annurev.nu.10.070190.000505 